\title{
FEEDING VALUE OF PROCESSED HORSE EYE BEAN (MUCUNA URENS) MEAL AS ALTERNATIVE PROTEIN SOURCE IN PULLET CHICKS' DIETS
}

\author{
O. O. EFFIONG, E. O. EKPE AND M. O. NKANG
}

(Received 9 June 2015; Revision Accepted 8 July 2015)

\begin{abstract}
The study was designed to evaluate the performance of pullet chicks fed graded levels of processed horse eye bean meal (HEBM) as partial replacement for soybean meal. The cracked beans were subjected to three processing methods viz: soaking in plain water for 48 hours, cooking for 90 minutes, and toasting on open fire at $100^{\circ} \mathrm{C}$ after sundrying for seven (7) days. The processed beans were milled to pass through a four(4) $\mathrm{mm}$ mesh and used for diet formulation. Six experimental diets were formulated each at brooding and rearing phases, with diet 1 as control, while soybean meal in the control diets were replaced with the horse eye bean meal (HEBM) at 15, 30, 45, 60 and $75 \%$ in diets 2, 3, 4, 5, and 6, respectively. Three hundred and sixty (360) one day-old Lohman black pullet chicks were used at brooding phase, while two hundred and seventy (270), 56 days old chicks were used during the rearing phase of the experiment. Chicks were divided into six (6) groups on weight equalization bases and groups randomly placed on one of the six diets. The feeding trials lasted for eight weeks at brooding stage and twelve weeks during rearing period. Data generated were statistically analysed using analyses of variance procedures. The results revealed that level of HEBM in the diet did not significantly influence the average daily feed intake, average daily weight gain and feed conversion ratio. Cost of feed consumed and cost per $\mathrm{kg}$ weight gain were significantly reduced with the inclusion of HEBM in pullet chicks' diets. It was concluded that 45 per cent of the soybean meal could be replaced by the HEBM in diets of pullets at the chick phase while HEBM can replace $60 \%$ of the soybean meal in the pullets' diet at rearing phase.
\end{abstract}

KEYWORDS: Horse eye bean, anti-nutrients, processing techniques, pullet chicks, brooding and rearing phases.

\section{INTRODUCTION}

Intensive poultry production has been identified as one of the means of attaining animal protein sufficiency in the diet of the average Nigerian (Ani and Adiegwu 2005). Nigeria poultry industry is, however, facing tremendous setback and is on the verge of collapse arising from high cost of poultry feed, which accounts for $70-80 \%$ of the total cost of poultry production. The high cost of poultry feed has been traced to the increasing cost of maize, soybean and groundnut which are the main conventional sources of energy and protein, respectively (Effiong et al., 2013). A possible solution to the escalating cost of these ingredients is to explore the potentials of alternative feedstuffs as partial or total replacement for the expensive conventional feed ingredients.

The alternative vegetable protein being considered in this study is the horse eye bean (Mucuna urens) meal. Studies on the nutrient composition showed that the bean is a good source of protein (25$35 \%)$, carbohydrate $(50-80 \%)$ and fat $(8-11 \%)$. Effiong and Umoren, (2011) reported Glutamic acid, aspartic acid and leucine as the major amino acids in the horse eye bean. Umoren et al., (2007) had reported that raw horse eye bean did not support growth of broilers and rats. This, they attributed to the presence of some anti nutritional factors which were present in the raw and cooked beans. The anti-nutritional factors in the horse eye bean meal include trypsin inhibitor, lectins, phytates, phenols, cynogenic glycosides, tannins and L3, 4 dihydroxyacetone (Effiong and Umoren, 2011).

Effiong and Umoren (2011) had recommended a multi-processing technique (combined soaking and cooking for 48 hours and 90 minutes, respectively and toasting) as processing method in eliminating the anti nutritional factors in the horse eye bean. They noted that the adopted processing methods reduced the levels of phytates, tannins, phenols, $\mathrm{HCN}$ and oxalates by 49 , 30,87 and $63 \%$, respectively.

The objective of this study was therefore to determine the optimum replacement level of the soybean meal by the processed horse eye bean meal (HEBM) in the diet of pullet chicks at brooding and rearing phases.

\section{MATERIALS AND METHODS}

Processing of the horse eye bean

The horse eye bean was processed using methods that

O. O. Effiong, Department of Animal Science, University of Calabar, Calabar, Nigeria.

E. O. Ekpe, Department of Animal Science, University of Calabar, Calabar, Nigeria.

M. O. Nkang, Department of Animal Science, University of Calabar, Calabar, Nigeria. 
local farmers can easily adopt. The methods were Soaking cracked beans in fresh clean water for 48 hours at room temperature $\left(37^{\circ} \mathrm{C}\right)$, cooking for 90 minutes on open fire at $100^{\circ} \mathrm{C}$ (timing started from the point of boiling), and toasting sun-dried bean in frying pot, on open fire for 15 minutes. The beans were then milled using $4 \mathrm{~mm}$ screened hammer mill and thereafter used for feed formulation.

\section{Experimental diets}

Six (6) diets each were formulated during brooding and growing phases to provide 20 per cent crude protein and approximately $2,800 \mathrm{kcal} \mathrm{ME} / \mathrm{kg}$ of metabolizable energy and 15 per-cent crude protein and $2700 \mathrm{kcal}$ $\mathrm{ME} / \mathrm{kg}$ of metabolizable energy, respectively (Table 1 ). Diet 1 was the control, containing soybean meal as sole plant protein. Diets 2 to 6 contained the HEBM, replacing $15,30,45,60$ and 75 per cent of soybean meal (SBM), respectively in the diets. The diets were presented in the form of mash. 
FEEDING VALUE OF PROCESSED HORSE EYE BEAN ( MUCUNA URENS) MEAL

TABLE 1: Composition of the experimental diet (\%)

\begin{tabular}{|c|c|c|c|c|c|c|c|c|c|c|c|c|}
\hline \multirow{2}{*}{ Ingredients } & \multirow[b]{2}{*}{0} & \multicolumn{6}{|c|}{ Replacement levels (\%) (Starter mash) } & \multicolumn{5}{|c|}{ Replacement levels (\%) (Grower mash) } \\
\hline & & 15 & 30 & 45 & 60 & 75 & 0 & 15 & 30 & 45 & 60 & 75 \\
\hline Maize & 53.0 & 51.0 & 48.6 & 45.6 & 42.1 & 37.6 & 57.0 & 56.2 & 55.3 & 54.5 & 52.5 & 50.5 \\
\hline Fish meal & 4.0 & 4.0 & 4.0 & 4.0 & 4.0 & 4.0 & 2.5 & 2.5 & 2.5 & 2.5 & 2.5 & 2.5 \\
\hline Soybean meal & 24.5 & 22.5 & 20.2 & 17.5 & 14.2 & 10.0 & 8.3 & 7.8 & 7.1 & 6.0 & 5.1 & 3.7 \\
\hline Horse eye bean meal & - & 4.0 & 8.7 & 14.4 & 21.2 & 29.9 & - & 1.4 & 3.0 & 4.0 & 7.7 & 11.1 \\
\hline Palm kernel cake & 4.0 & 4.0 & 4.0 & 4.0 & 4.0 & 4.0 & 6.0 & 6.0 & 6.0 & 6.0 & 6.0 & 6.0 \\
\hline Wheat offal & 11.0 & 11.0 & 11.0 & 11.0 & 11.0 & 11.0 & 22.0 & 22.0 & 22.0 & 22.0 & 22.0 & 22.0 \\
\hline -Vitamin/mineral premix & 0.5 & 0.5 & 0.5 & 0.5 & 0.5 & 0.5 & 0.5 & 0.5 & 0.5 & 0.5 & 0.5 & 0.5 \\
\hline Bone meal & 2.0 & 2.0 & 2.0 & 2.0 & 2.0 & 2.0 & 3.0 & 3.0 & 3.0 & 3.0 & 3.0 & 3.0 \\
\hline Salt & 0.5 & 0.5 & 0.5 & 0.5 & 0.5 & 0.5 & 0.4 & 0.4 & 0.4 & 0.4 & 0.4 & 0.4 \\
\hline Lysine & 0.3 & 0.3 & 0.3 & 0.3 & 0.3 & 0.3 & 0.2 & 0.2 & 0.2 & 0.2 & 0.2 & 0.2 \\
\hline Methionine & 0.2 & 0.2 & 0.2 & 0.2 & 0.2 & 0.2 & 0.1 & 0.1 & 0.1 & 0.1 & 0.1 & 0.1 \\
\hline Total & 100 & 100 & 100 & 100 & 100 & 100 & 100 & 100 & 100 & 100 & 100 & 100 \\
\hline \multicolumn{13}{|l|}{ Calculated analysis } \\
\hline Crude protein (\%) & 20.00 & 20.00 & 20.00 & 20.00 & 20.00 & 20.00 & 15.00 & 15.00 & 15.00 & 15.00 & 15.00 & 15.00 \\
\hline $\mathrm{ME}(\mathrm{Kal} / \mathrm{kg})$ & 2800 & 2801 & 2803 & 2806 & 2807 & 2809 & 2,718 & 2,719 & 2,719 & 2,723 & 2,720 & 2,720 \\
\hline \multicolumn{13}{|l|}{ Determined analysis } \\
\hline$\%$ Crude protein & 19.98 & 19.96 & 20.01 & 20.04 & 20.08 & 20.00 & 15.06 & 15.00 & 15.00 & 15.02 & 15.05 & 15.03 \\
\hline $\mathrm{ME}(\mathrm{Kcal} / \mathrm{kg})$ & 2796 & 2798 & 2800 & 2802 & 2805 & 2800 & 2709 & 2717 & 2718 & 2719 & 2715 & 2714 \\
\hline
\end{tabular}

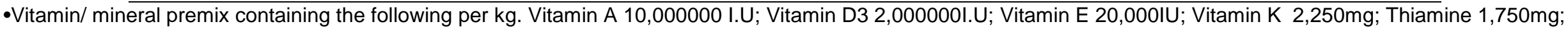

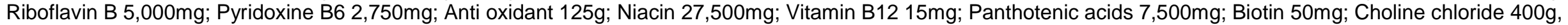
Manganese 80g; Zinc 50g; 1ron 20g; Ccopper, 5g; lodine 1.2g; Selenium 200mg; Cobalt 200mg 


\section{Experiment birds and design}

A total of three hundred and sixty (360) one day-old, Lohman black pullet chicks were used for this study during brooding phase. The chicks were weighed and grouped according to their body weights into six (6) groups each of fifty (60) chicks. Within each group, they were further divided into three (3) replicates of twenty (20) birds each such that the overall mean weights and weight ranges were similar across the groups. Groups were randomly allocated to the six experimental diets in a completely randomized design. Each diet was fed as mash throughout the experimental period. Feed and water were provided ad libitum.

At growing phase, two hundred and seventy (270), 8 weeks -old pullets were selected, weighed and grouped according to their body weight into six (6) groups of forty-five (45) birds. Each group had three replicates of fifteen birds. Groups were randomly allocated to the six grower mash (test diets) in a completely randomized design. The experiment lasted for 56 days for the brooding phase and 12 weeks during the rearing/growing phase.

\section{Data collection and analyses}

Feed intake (pen basis) was measured daily; the weights of birds were taken weekly. Both the feed intake and weight gain were used to calculate the feed conversion ratio. Economics of feeding HEBM to growing pullets was evaluated.

Data generated from the experiment, were statistically analyzed, using the analyses of variance procedure. Significant means were separated by Duncan's new multiple range test (Duncan, 1955).

\section{RESULTS AND DISCUSSION}

Data for the performance of pullet chicks fed diet containing graded levels of processed horse eye bean meal are presented in Tables 2 and 3 .

TABLE 2: Performance of pullet chicks fed diets containing graded levels of HEBM during brooding phase.

\begin{tabular}{|c|c|c|c|c|c|c|c|}
\hline \multirow[b]{2}{*}{ Parameters } & \multirow[b]{2}{*}{0} & \multirow[b]{2}{*}{15} & \multicolumn{3}{|c|}{ Levels of HEBM (\%) } & \multirow[b]{2}{*}{75} & \multirow[b]{2}{*}{ SEM } \\
\hline & & & 30 & 45 & 60 & & \\
\hline Initial weight/bird (g) & 50.00 & 50.00 & 49.58 & 50.83 & 50.42 & 50.42 & \pm 0.12 \\
\hline Final weight/bird $(\mathrm{g})$ & 472.45 & 449.29 & 429.55 & 426.77 & 401.33 & 358.33 & \pm 2.45 \\
\hline Weight Gain/bird (g) & 422.45 & 399.29 & 379.55 & 375.28 & 350.91 & 308.33 & \pm 2.46 \\
\hline $\begin{array}{l}\text { Average daily weight gain/bird } \\
\text { (q) }\end{array}$ & 7.54 & 7.13 & 6.78 & 6.70 & 6.27 & 5.51 & \pm 0.46 \\
\hline $\begin{array}{l}\text { Average daily feed intake/bird } \\
\text { (g) }\end{array}$ & 29.59 & 27.61 & 28.60 & 28.07 & 28.82 & 28.74 & \pm 0.32 \\
\hline Feed conversion ratio & 3.96 & 3.87 & 4.22 & 4.19 & 4.60 & 5.22 & \pm 0.19 \\
\hline Cost/kg feed $(\mathrm{N})$ & 84.94 & 79.74 & 79.34 & 78.02 & 78.15 & 78.02 & \pm 0.63 \\
\hline Cost of feed consumed $(\mathrm{N})$ & $140.74^{\mathrm{a}}$ & $123.29^{\mathrm{cd}}$ & $127.07^{\mathrm{b}}$ & $122.64^{\mathrm{cd}}$ & $126.13^{b}$ & $124.41^{\mathrm{bc}}$ & \pm 1.01 \\
\hline Cost/kg weight gain $(\mathrm{N})$ & $333.15^{\mathrm{C}}$ & $308.77^{\mathrm{e}}$ & $334.79^{c}$ & $323.12^{d}$ & $359.44^{\mathrm{b}}$ & $403.49^{\mathrm{a}}$ & \pm 2.26 \\
\hline
\end{tabular}

Means with different superscripts on the same row are significantly different $(P<0.05)$ 
Table 3: Performance of growing pullet chicks fed graded levels of processed horse eye bean meal

Percentage levels of HEBM replacement

\begin{tabular}{|c|c|c|c|c|c|c|c|}
\hline Parameters & 0 & 15 & 30 & 45 & 60 & 75 & SEM \\
\hline Initial weight/bird (g) & 472.45 & 472.29 & 470.50 & 470.77 & 469.44 & 469.75 & \pm 0.47 \\
\hline Final weight/bird (g) & $1135.83^{a b}$ & $1142.85^{\mathrm{ab}}$ & $1191.53^{\mathrm{a}}$ & $1206.28^{a}$ & $1376.28^{a}$ & 10240.00 & \pm 3.14 \\
\hline Total weight gain/bird(g) & $663.38^{a b}$ & $670.56^{\mathrm{ab}}$ & $721.03^{a}$ & $735.51^{\mathrm{a}}$ & $906.84^{a}$ & 554.25 & \pm 43.3 \\
\hline $\begin{array}{l}\text { Average daily weight } \\
\text { gain/bird }(\mathrm{g})\end{array}$ & $7.90^{a b}$ & $7.98^{a b}$ & $8.58^{a}$ & $8.76^{a}$ & $10.79^{a}$ & $6.60^{c}$ & \pm 3.60 \\
\hline $\begin{array}{l}\text { Average daily feed } \\
\text { intake/bird }(\mathrm{g})\end{array}$ & $47.02^{a}$ & $40.54^{b}$ & $46.08^{a}$ & $43.05^{b}$ & $35.92^{a}$ & $47.40^{\mathrm{b}}$ & \pm 7.05 \\
\hline Feed conversion ratio & 6.32 & 5.39 & 5.5 & 5.20 & 4.48 & 6.25 & \pm 0.26 \\
\hline \multirow{2}{*}{$\begin{array}{l}\text { Cost } / \mathrm{kg} \text { of feed }(\mathrm{N}) \\
\text { Cost of feed consumed } \\
\text { (N) }\end{array}$} & 66.94 & 61.74 & 61.34 & 60.02 & 60.15 & 59.37 & \pm 1.03 \\
\hline & $88.36^{\mathrm{a}}$ & $69.77^{\mathrm{bc}}$ & $79.13^{b}$ & $72.62^{b}$ & $78.00^{b}$ & $59.96^{d}$ & \pm 3.39 \\
\hline Cost/kg weight gain ( $\mathrm{N}$ ) & $133.17^{\mathrm{a}}$ & $103.98^{\mathrm{b}}$ & $109.75^{\mathrm{b}}$ & $98.67^{\mathrm{bc}}$ & $86.00^{\mathrm{C}}$ & $108.23^{b}$ & $\pm \quad 5.80$ \\
\hline
\end{tabular}

Means with different superscripts on the same horizontal line are significantly $(\mathrm{P}<0.05)$ different

SEM- Standard error of means

HEBM - Horse eye bean meal

The results show that increasing dietary level of processed HEBM did not significantly (P> 0.05) influence the final body weight and the average daily weight gains of the chicks during brooding, but increased the weight gain significantly $(P<0.05)$ at growing phase. The results revealed that values were slightly depressed with increased level of HEBM in the diet at brooding phase, while at growing phase, the situation was reversed as birds on higher levels of HEBM performed better, except at $75 \%$ level of inclusion. This development shows the ability of the test sample to promote the birds' growth. The average daily weight gain recorded in this study was similar to the value $7.13 \mathrm{~g}$ reported by Amaefule and Obioha (2005) for pullet chicks fed diets containing processed pigeon pea seed meal as replacement for soybean meal.

Dietary level of HEBM in the diet did not significantly $(P>0.05)$ influence the average daily feed intake during brooding phase, but significantly influenced the intake of birds at growing phase. The result of this experiment was, however, lower than the values reported by Ani (2008) for pullet chicks fed processed velvet beans diet. Variation in the average daily feed intake during growing phase did not follow any pattern and therefore could not be attributable to any dietary effects.

Efficiency of feed utilization by the chicks was poorer with increasing dietary level of HEBM at brooding phase. This may be attributed to the inability of the birds to effectively utilize the diets, probably due to the presence of Non starch polysaccharides (NSP) in the diets (Nadeem et al., 2005; Balamurugan and Chandrascharan, 2010). The significant improvement in the FCR during growing phase could be due to the facts that birds at this stage may have developed adequate digestive enzymes to effectively handle the feeds. Generally, High FCR values observed at growing phase could be attributed to a shift of attention of the pullets from growth to the reproductive organs development.

Cost $/ \mathrm{Kg}$ of feed slightly decreased with an increase in the dietary level of horse eye bean meal (HEBM). Values were statistically similar across the treatment groups. Birds fed control diet had significantly $(P<0.05)$ higher cost of daily feed intake than birds on the experimental diets during brooding phase but were statistically similar during rearing phase. Birds fed $15 \%$ and $30 \%$ HEBM diets had the least cost of feed consumption at brooding phase while birds on $75 \%$ HEBM diet recorded the least cost of feed consumption during rearing. The differences were significant $(P<0.05)$ among treatment groups.

The cost $/ \mathrm{Kg}$ weight gain was significantly different among the treatment groups. Chicks on treatment diets had the lowest cost $/ \mathrm{kg}$ weight gain relative to the control group. Birds on 60\% HEBM diet had the least cost $/ \mathrm{kg}$ weight gain, followed by those fed $45 \%$ HEBM diet. The significant reduction in the cost of feed $/ \mathrm{kg}$ weight gain of birds fed experimental diets during rearing phase maybe attributed to their outstanding growth.

\section{CONCLUSION}

The result of the feeding trial revealed up to $30 \%$ of the soybean meal (SBM) could be replaced by the processed horse eye bean meal (HEBM) at brooding phase while $60 \%$ of the SBM could be replaced by HEBM during rearing phase without any deleterious effects on the birds.

\section{REFERENCES}

Amaefule, K. U and Obioha, F. C., 2005. Performance of pullet chicks fed raw or processed pigeon 
pea (Cajanus cajan) seed mean diets. Livestock Research for Rural Development, 17, (3): 1-9.

Ani, A. O., 2008. The feeding value of processed velvet beans (Mucuna pruriens) for pullet chicks. J. of Tropical Agriculture, Food, Environment and Extension, 7, (2): 149-155.

Ani, A. O and Adiegwu, L. U., 2005. The feeding value of velvet beans (Mucuna pruriens) to weaner rabbits. Proceeding of the $30^{\text {th }}$ Annual Conference of Nigerian Society for Animal Production. University of Nigeria, Nsuka. $20^{\text {th }}-$ $24^{\text {th }}$ March, 2003. Pp186-189.

Balamurugan, R and Chandrasekaran, D., 2010. Effect of multi- enzyme supplementation on weight gain, feed intake and feed efficiency and blood glucose in broiler chickens. Indian J. of Sc. and Tech. 3, (2): 1-15.

Effiong, O. O and Umoren, U. E., 2011. Effect of MultiProcessing Techniques on the chemical composition of Horse eye bean (Mucuna urens). Asian J. of Animal Sciences. 5, (5): $340-348$.

Effiong, O. O., Wogar, G. S. I and Umana, D. E., 2013. Comparative Evaluation of Sweet Orange waste meals and wheat offal as fibre sources in growing rabbit's diets. J. of Agric. Sc. 5, (3): $164-169$.

Duncan, D. B. 1955. New Multiple Range est. Biometrics, (11): 1-42.

Nadeem, M. A., Anjum, M. I., Khan, A. G and Azim, A., 2005. Effect of dietary supplementation of non - starch polysaccharide degrading enzymes on growth performance of broiler chicks. Pakistan Vet. J., 25, (4): 183-187.

Umoren, U. E., Effiong, O. O and Akpan I. A., 2007. Nutritional Evaluation of the horse eye bean (Mucuna urens): Effect of processing on the chemical composition. J. of Food, Agriculture and Environment, 5, (2): 128-131. 